\title{
Comparative Study of the Electromyographic Activity of the Lips Orbicular Muscle in Patients with and without Cleft Palate
}

\author{
Carrillo Rivera Jorge ${ }^{1, *}$, Daniel Flores Rodríguez ${ }^{2}$, Medina Andrade Luis Angel ${ }^{3}$, Rodriguez \\ Rodriguez Carlos Eduardo ${ }^{4}$, Eduardo Vidrio Duarte ${ }^{4}$, Paz Mendoza Adriana ${ }^{4}$, Samaniego \\ Martinez Yazmin ${ }^{5}$, Valdés Hernández Brenda Elizabeth ${ }^{5}$, Flores Galicia Hisela Viridiana ${ }^{5}$, \\ Haizel Valencia Romero ${ }^{6}$, Edson Antonio Garcia Díaz ${ }^{6}$ \\ ${ }^{1}$ Stomatologist with specialization in oral and maxillofacial surgery, General Hospital "Dr. Darío Fernández \\ Fierro", ISSSTE, México City \\ ${ }^{2}$ General Surgery Resident, Veracruz General Hospital, México \\ ${ }^{3}$ General Surgery Department, General Zone Hospital 1A, Instituto Mexicano del Sequro Social, México City \\ ${ }^{4}$ La Salle University, Angeles Metropolitano Hospital, Mexico City, México \\ ${ }^{5}$ México Valley University UVM, General Zone Hospital 1A Rodolfo de Mucha Macias, México City, México \\ ${ }^{6}$ Mexico National Autonomous University UNAM, General Zone Hospital 1A Rodolfo de Mucha Macias, Mexico \\ City, México
}

\begin{abstract}
*Corresponding Author: Dr. Jorge Arnulfo Carrillo Rivera. Dental and Maxilofacial rehabilitation, consulting room 124. Avenue Juárez Number 8 Col. Las Margaritas, Tlalnepantla Estado de México. Tel 5361 86 77. E-mail: jcarrillo_99@yahoo.com
\end{abstract}

\begin{abstract}
The electromyography $(E M G)$ is the study of electrical activity in the muscles. The first study was performed by Piper in 1912, and he registered the voluntary contraction potentials using surface electrodes and a wire galvanometer. Actually the register and interpretation of electromyographic activity is an important tool in the diagnosis and rehabilitation of the muscles mechanic activity. The objective of this study is to evaluate the electromyographic activity of the lips orbicular muscle during rest, phonation, chewing and swallowing in young patients with background of lip and cleft palate compared with patients without this pathology.
\end{abstract}

Keywords: Electromyography, lip and cleft palate, phonation, swallow and chewing

\section{INTRODUCTION}

The electromiography begins at the end of the XVIII century with the discovery of animal electric stimulation by Galvany, who achieved a muscular contraction by stimulation of a nerve without metal use for this purpose. This finding were reproduced by Humbold in 1797 and Marrecucci in 1844. Duchenne of Eculogne, in 1833 saw that a muscle could be stimulated with electricity from a cutaneous surface by electrodes, and was the first to use the current for stimultaion. ${ }^{1}$ In 1922 Gasser and Erlanger contributed one of the greatest advances in technology, the cathode ray osciloscope, that eliminate the mechanical limitations of the galvanometers. At the same time a new advance in the neurophysiologic knowledge was produced, because Hoffmann in 1922 discovered the monosynaptic reflexes in the man by stimulation of the tibial nerve and registering the action potential of soleus muscle ${ }^{2}$.

The contractile unit of the musculature of the skeleton is the muscular fiber, a cylindrical cell with a diameter of $50 \mu \mathrm{m}$, that after stimulation generates a contracts developing force. A muscle consists of parallel bundles of muscular fibers. The activation of each muscle fiber is completed through the axon of the motor nerve fiber that innervates it. According to the position and function of the muscle, the number of muscular fibers innervated by the same axon could vary between one to more than a thousand. The complex constituted by the motor nerve in the dorsal spine, their axon and the muscular fibers innervated by this constitutes the basic functional unit of the muscular system and is called motor unit. When the nerve 
potential of action is reached, the acetylcholine is released causing a local depolarization of the muscle fiber membrane. The neurotransmitter is rapidly neutralized by the acetylcholine estereate, allowing a free myoneural union for another excitatory impulse. ${ }^{1,2}$

Actually the electromyography is defined as a technique of registry of the electrical signal originated in the muscular fiber and is transmitted through the adjacent tissues that allow us to register the muscular activity during different actions. (Kimura, 1989; Buchthal, 1991; Miller, 1991; Moyers, 1962). ${ }^{3}$

One of the objectives of electromyography is to evaluate the motor and sensitive function of the neuromuscular system through the register of the electric stimuli observed in an electromagnetic wave; this research of the correlation between the form and function of the muscular apparatus have been applied to the research in quantitative oral physiology in chewing, swallowing and phonation. ${ }^{1,5,9}$

From the technical view, the electromyographic activity registries are influenced by biological variables like sex, age, health of masticatory system, the occlusion stress, facial types, contraction level and instrumental factors such as the type of electrodes ${ }^{8-13}$, the amplification of the contact surface area, the relation signalsound and the signals interpretation technique ${ }^{14-}$ 16. All the mentioned factors can influence the reproducibility of records inclusive in the same day $^{20,21}$. This problem is not limited to electromyography, and could be appreciated in many imaging studies like blood pressure or glycosylated hemoglobin ${ }^{22,23}$.

Blair and Smith in 1986, mention that the surface electrodes have two advantages over the needle eletrodes to analize the electromiographic activity of orbicular muscle of the lips, the first is that it is not invasive and the second is that this muscle is constituted by the union of left and right muscle fibers. One disadvantege of the use of surface electrodes are the reflex pick signals by the thinness of the skin and connecive tissue, and the action potentials of adjacent nerve terminals. ${ }^{24}$

The objective of surgical techniques for repair of cleft lip are the restoration of the anatomical form and muscular function, a fundamental point to prevent the secondary eskeletal changes in the facial middle third (Kernahan and Bauer, 1983; Joos, 1987). ${ }^{25,26}$ Classically growing differences in the facial middle third of this patients were attributed to a iatrogenic effect of the palate surgical correction. In 1977 Bardach and Eisbach mention that the palate correction always produce tension against the adjacent maxilar and that this affects significatively the normal growing of maxilar. ${ }^{27}$ Although this, in 1990 Bardach change his hypothesis mentioning that is the lip reconstruction and not the palate reconstruccion that must be considered like the factor that affects the dentofacial deformities in this population.

\section{MAterials AND MethodS}

Six patients were included in the study, divided in two groups, three in the control group and three in the experimental group, both groups were conformed by two woman and a men between 12 and 16 years old.

The study was explained to each one of the patients and an informed consent was obtained.

The patients facial skin was cleaned with alcohol and two chloride/silver electrodes (Nicolet, Biomedical Inc. Wisconsyn USA) were placed with conductor gel Núprep TM (Weaver y Co, Aurora, CO. USA) and fixed with micropore ${ }^{\mathrm{MR}}$ in the upper orbicular muscle of the lips, and one reference electrode over the sternocleidomastoid muscle according to Carbajal et. al. technique ${ }^{23}$ (Figure 1).

Patients were sitted in a reposet, with the head with the Frankfort horizontal plane parallel to the floor and eyes open in rest position for 90 seconds to realice the calibration test, with a resolution of 12 bits and sample frequency of 10 khz (Figure 2).

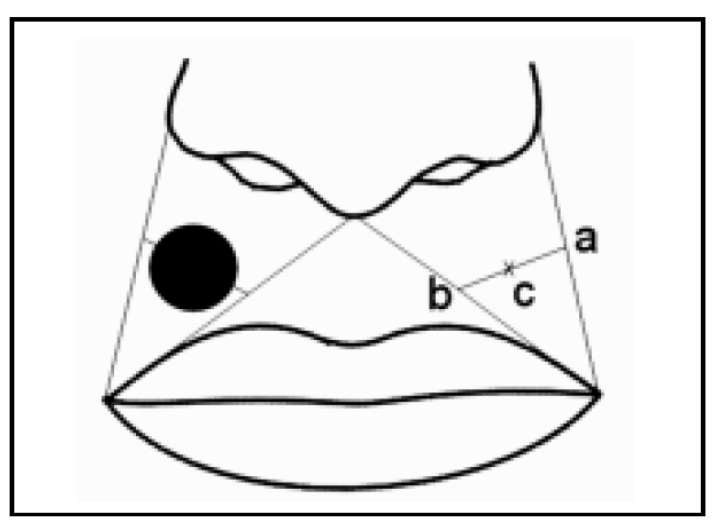

Figure 1. Carbajal et. al. electrodes placement. a. Line between the corners of the mouth and the lateral nose wing. $b$. Line between the corners of the lips and the subnasal point, c. Point between the electrodes marked with and $x$. 


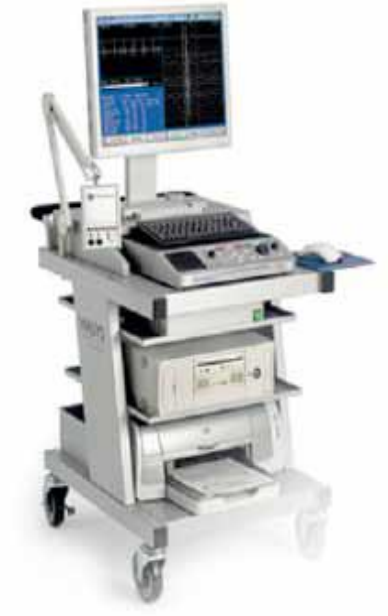

Figure 2. Viking Quest Nicolet Electromyograph (Viasys Healthcare)

Posteriorly the measurement at rest was performed. Subject was instructed to realice a swallowing of saliva after drinking $3 \mathrm{ml}$ of water, for chewing $1 \mathrm{~cm}^{3}$ of apple was used.
The last probe was the articulation of the bilabial phonemes $/ \mathrm{p} /, / \mathrm{b} /, / \mathrm{m} /$ followed by the consonant /a/ for the phonation probe and register of all the data.

Each probe was repeated three times with a rest period of 90 seconds between measurements obtaining the electromiographic registry in a curve of wave amplitude of the peak activity in $\mu \mathrm{V}$, and the highest value was selected for their analysis.

The detected signals at rest by the surface electrode are about 5 to $10 \mu \mathrm{V}$, with a frequence less than $10 \mathrm{~Hz}$. The spontaneous activity represent changes in the basal line that were discarded to register only the changes when the patients complete the requested activities. The speed of registry for the action potentials were 60 to 100 milimeters per second.

After the completed instructions were carried out and registered the study was completed with the removal of electrodes and cleaning of the skin. (Figure 3.)

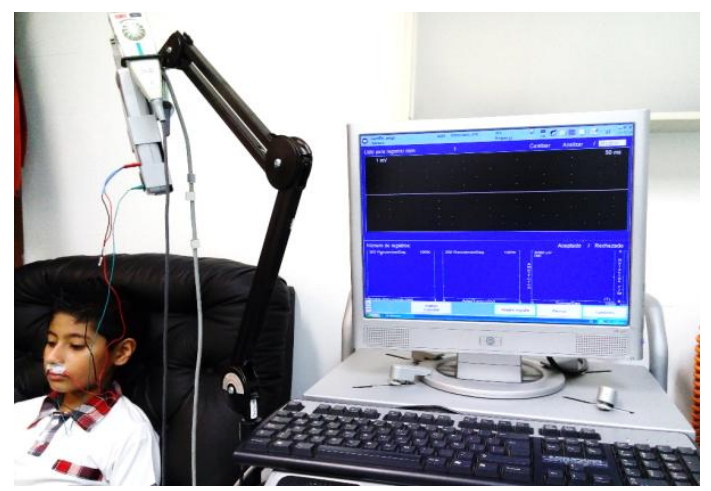

Figure 3. Position of the patient in a reposet seat and electromyograph calibration

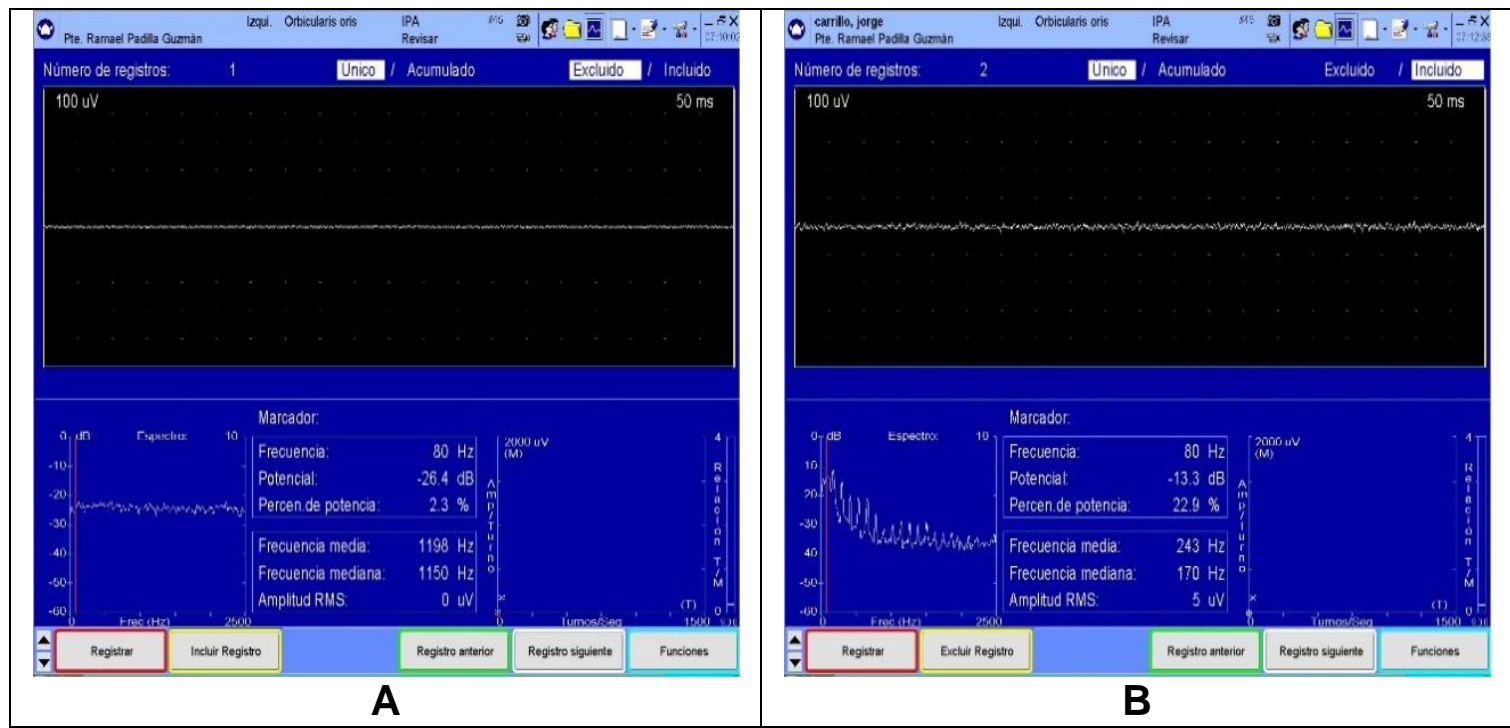


Comparative Study of the Electromyographic Activity of the Lips Orbicular Muscle in Patients with and without Cleft Palate

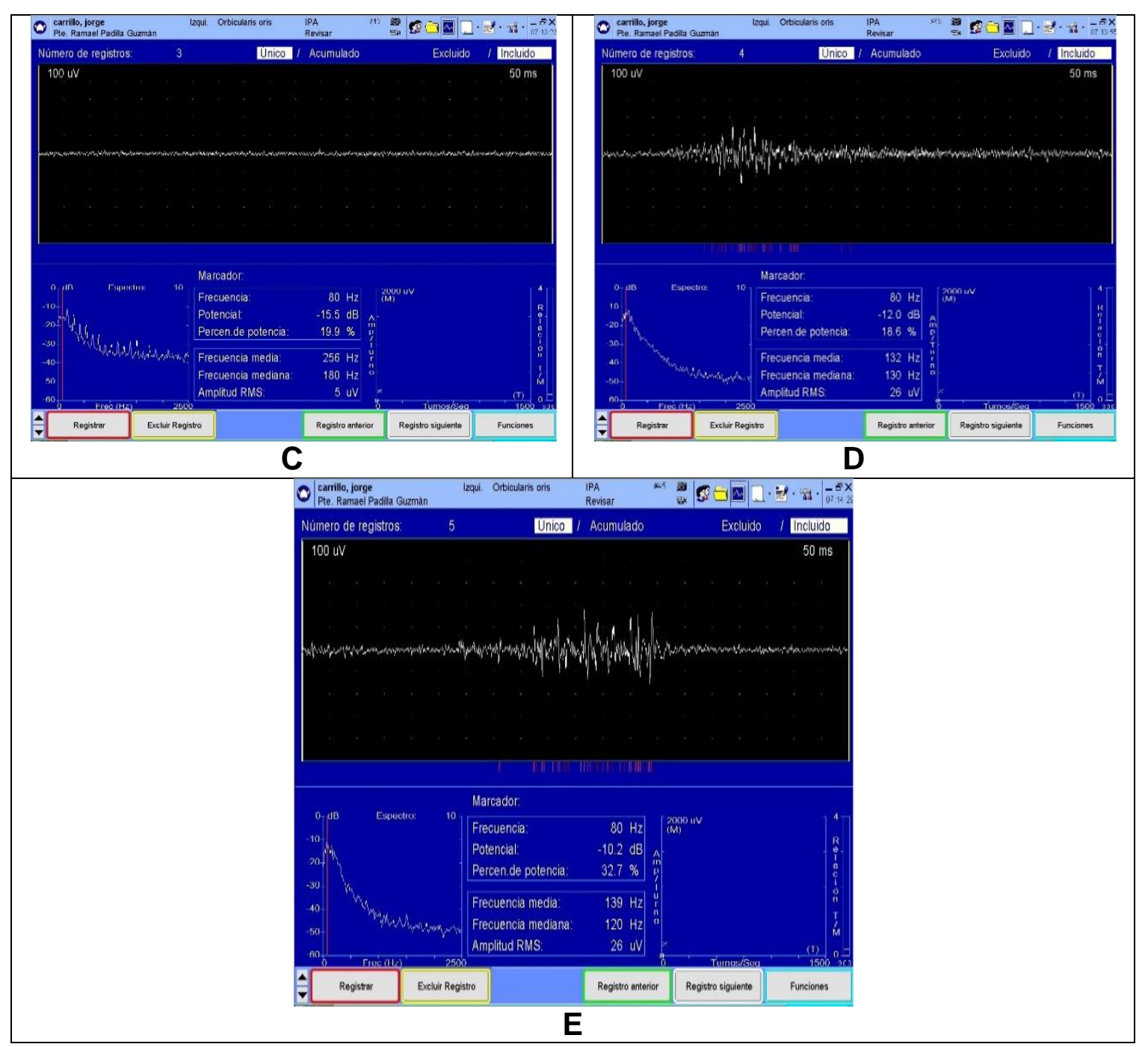

Figure 4. Electromyographic images during different test. A. Electromyographic calibration. B. Rest. C. Swallowing. D. Chewing. E. Phonation (Phonema /P/).

The statistical test of Wilcoxon was used to compare two independent samples. The null hypothesis was considered (H0). The popullation media of group 1 is higher or equal that the one for group 2. The alternative hypothesis was that the popullation media 1 is smaller compared with the group 2 media. By the sample bigger than 8 patients a normal distribution probe was used, and the stadistic value of the probe was calculated with . $\mathrm{Zw}=(\mathrm{W}-$ Media $) / \operatorname{Root}($ Variance $)$, where $\mathrm{W}=$ Sum of sample 1 ranges , Media= $\mathrm{n} 1 *(\mathrm{n} 1+\mathrm{n} 2+1) / 2$ and Variance $=$ $\mathrm{n} 1 *_{\mathrm{n} 2} *(\mathrm{n} 1+\mathrm{n} 2+1) / 12$, with $\mathrm{n} 1$ and $\mathrm{n} 2$ as the number of observations in the respective samples. The value of $p$ would be $P(Z)$ of left tale. The $Z \alpha$ critical value was calculated from the significance grade $\alpha$, using the normal distribution tables to stablish the decision rule.

\subsection{Rule Of Decision}

ARC Journal of Surgery
To the one left tale probe, if the $\mathrm{Zw}$ value is higher than $Z \alpha$ it is then accepted Ho, the other way Ho is rejected and Ha accepted.

\section{RESUltS}

In the control group the muscular activity was observed during the requested function as a fast reference to know and compare with the experimental group. Although the registered numbers represents the changes of the electric impulses in the muscular fibers, this numbers can vary between each patient.

The electromyiographic activity of the orbicular muscles in patients operated of cheloplasty

was appreciated with an increasing of action potentials and a higher energy consumption that affects the muscle growing, although there is homogeneity in the electromyiographic activity of the lips orbicular muscle during rest in both groups, there exist a significative difference (Graphic1). 


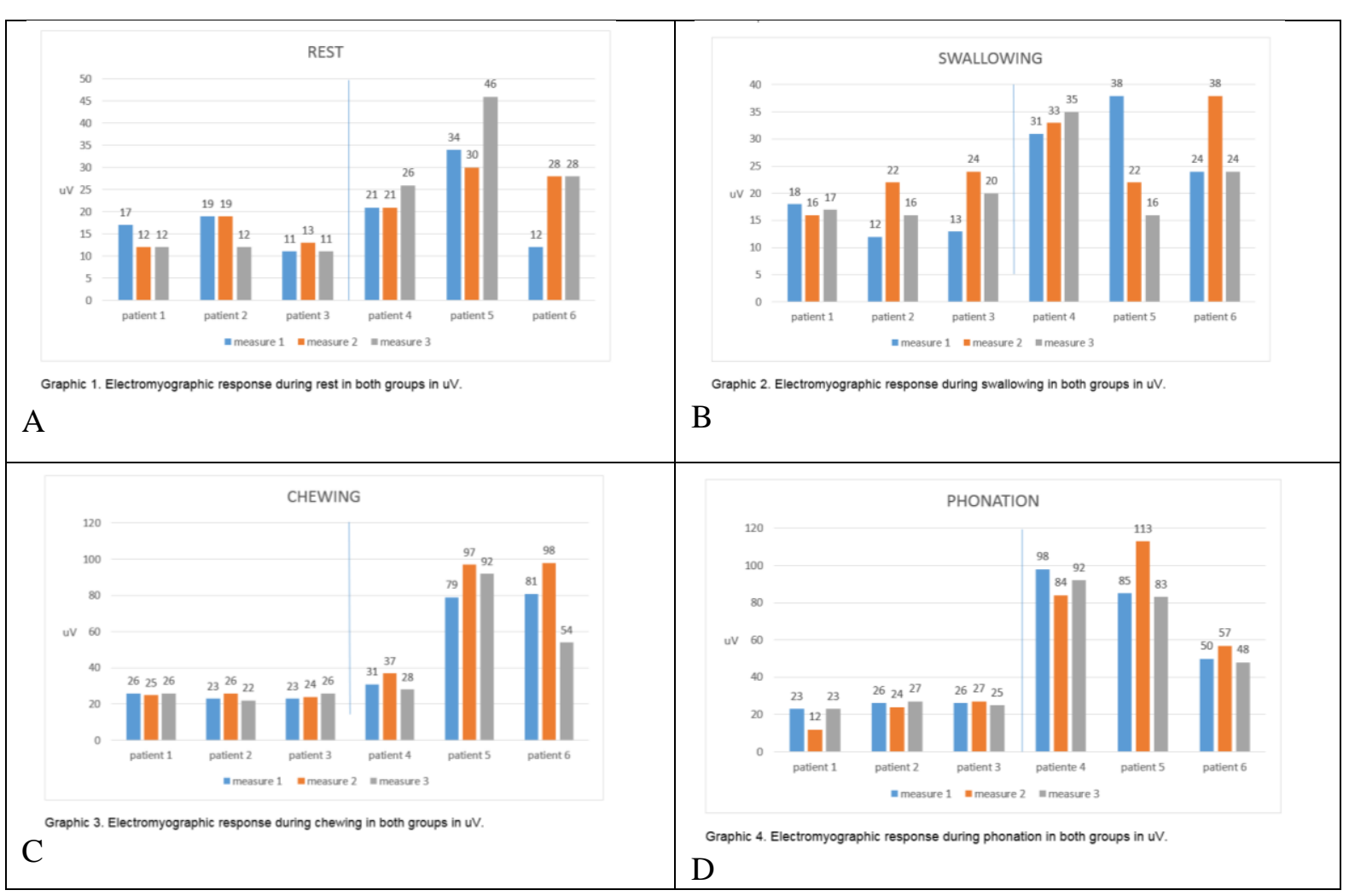

Graphic 1. Electromyographic response comparation between groups in $u V$ during A. rest. B. swallowing $C$. Chewing D Phonation.

The muscular activiy during swallowing is sligthly higher in the experimental group, and the motor units activity of the lips orbicular muscle of the lips reflex more voluntary action.

During chewing there exist a tendency of higher activity in the group with cleft lip and palate than in the control group with an increasing in the value of action potentials of the orbicular muscle of the lips.

In the bilabial phonemas test $/ \mathrm{ma} / \mathrm{ba} / \mathrm{pa} /$ there existed an increasing in the electromyographic activity in patients with cleft lip and palate compared with control group, specially in the /P/ phonema (Graphic 2).

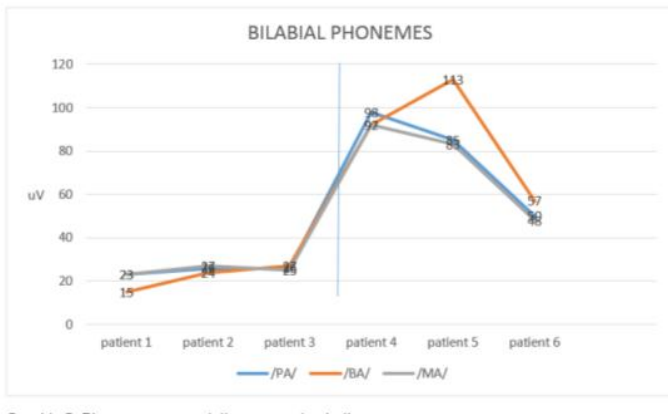

Graphic 2. Electromyographic response of phonemas. /P/B/M/ compared between groups

\section{DisCUSSION}

In the worldwide literature there are no diagnostic criteria for the excessive activity or defficient activity of the orbicular muscle of the lips in patients with cleft lip and palate. Although the superior lip position have been studied by the sof tissues cephalometry, it had been evaluated according to the vertical line that cross over the concavity that exist at the base of the upper lip (A point) and the relation with the position of inferior lip (point B). It have been demonstrated that the upper lip is protrusive or proinctive if it is well ahead of this line, and if it is behind this is retrusive, although this description leaves us with parafunctional limitants of the upper lip. Other author mention that to consider the lips morphologically and functionally normal, they must have contact between them without effort or contraction of the perioral muscles, where the lip contour in close position must be soft and $\operatorname{armonic}^{27-31}$. The lips incompetence is defined as the abscense of sealed or close of the lips, and when this happened the upper lip becomes hypotonic, flacid with bow shape, and the inferior lip becomes hypertonic. Some competent lips have addapted to the surgical correction of the lip cleft; although there exist a closure, is not a lip-lip closure, it is a lip-tooth- 
lip arrangement. The hyperactive lips are bigger, more red and moist that the normal or hypoactive ones. Sometimes the lips are correct in size but did not adquiere normal function. ${ }^{32,33}$

For the present study variables like surgical technique, age, surgeon, time between surgical correction and electromyiography were not considered for the analysis because this variables must influence drastically each patient result.

Secondary to the variety of amplitude in the studies of electrical signals, in the present study the maximum amplitude peaks were taken as the register measure. Although those limitants the studies using electromyography do not lose validity because the obtained results can help to differentiate between the clinical and functional characteristics of each analized patient.

Bardach and Eisbach (1977) indicated that the primary cleft lip repair always result in lip tension that transfers tension to the underlying maxilla, and mentioned that the sagital facial middle third developement is affected after the growing up ends.

This have been attributed to the contraction of scar tissue after surgery, suggesting that the lip function could have an important role in the maxilla developement (Goz, et al., 1985,1987).

This theory was confirmed in an experimental study in rabbits and dogs (Eisbach et al, 1978; bardach, 1990). One characteristic finding in the soft tissue of child with cleft lip and palate is a short upper lip (Smahel and Mullerova, 1986). To evaluate the functional importance of lip function and the face and maxilla morphology, Goz et. al. performed in 1987 an study of the muscular activity of the lip orbicular muscle with surface electrodes during rest They report an insufficient activity of the lip in patients with cleft lip and palate background, with an increasing in mucular activity during rest. Carvajal et. al. (1992) performed an study of the electromyographic acticity of the upper orbicular muscle in 15 child with cleft lip and palate after surgical correction during their first year of life (group 1), and compared it with 10 child without this background (group 2). They found a similar electromyographic activity during rest in both groups. During swallowing the activity was greater in group 1 . Genaro et al (1994) measured the electromyographic activity of upper lip wih surface electrodes during phonation to evaluate the lip function in child with cleft lip and palate correction. They compared 18 patients between 15 and 23 years old with cleft lip and palate corrected with 24 healthy child, and found that the amplitude of action potentials of the upper lip were higher in the patients of first group suggesting that if there is improvement in the upper lip activity the anormalities in the facial growing could be limited in this popullation. ${ }^{24}$

According to the results the electromyographic activity at rest is similar in patients with and without cleft lip and palate, but there is a significant difference during functional activities with a higher activity in patinets with cleft lip and palate due to the increase in the contribution of forces in the contraction of the superior orbicular of the lips muscle.

\section{CONClusion}

We can conclude that due to the importance of the lip function to the facial expression, chewing, phonation and swallowing, the abnormal activity of the lip during this functions could represents an adittional factor that compromises the integrity of the adjacent facial structures.

This study allow us to measure the muscle fiber activity to strengthen the rehabilitation therapy in an individualized manner.

\section{ETHICAL ASPECTS}

All patients assent and their parents signed informed consent to be part of this study.

\section{AKNOWLEDGEMENTS}

To the physicist and mathematician Abraham Gómez Ávalos for their dedication, patiense and prefessionalism.

\section{REFERENCES}

[1] Caballero K.,Duque LM., Ceballos S.,Ramírez JC.,Peláez A.Conceptos básicos del análisis electromiográfico.Rev.CES Odont.2002;15(1): 41-50.

[2] Barraquer-Bordas L. Neurología Fundamental. Barcelona: Ed. Toray SA; 1963. p. 502-67.

[3] Bardach J, Eisbach KJ. The influence of primary unilateral cleft lip repair of facial growth. Part I: Lip pressure. Cleft Palate Craniofac J. 1977;14:88-97.

[4] Bardach J, Mooney MP, Giedrojc-Juhara ZL. A comparative study of facial growth following cleft lip repair with or without soft tissue undermining: an experimental study in rabbits. Plast Reconstr Surg. 1982; 69:745-753. 
[5] Bardach J, Mooney MP. The relationship between lip pressure following lip repair and craniofacial growth: an experimental study in beagles. Plast Reconstr Surg. 1984;73:544-555.

[6] Eisbach KJ, Bardach J, Klausner EC. The influence of primary unilateral cleft lip repair on facial growth. Part II: Direct cephalometrics of the skull. Cleft Palate J. 1978;15:109-117.

[7] Goz G, Joos U, Schilli W. The influence of lip function on the sagittal and transversal development of the maxilla (Abstract 359). Presented at the Fifth International Congress on Cleft Palate and Related Craniofacial Anomalies. September 2-7, 1985; Monte Carlo, Monaco.

[8] Goz G, Joos U, Schilli W. The influence of lip function on the sagittal and transversal development of the maxilla in cleft patients. Scand J Plast Reconstr Surg Hand Surg. 1987;21:31-34.

[9] Pincivero DM.,Green RC.,Mark JD.,Campy RM.Gender and muscle differences in EMG amplitude and median frequency, and variability during maximal voluntary contractions of the quadriceps femoris.J Electromyogr Kinesiol.2000;10(3):189-196.

[10] Ferrario VF.,Sforza C.,D'Addona A.,Miani AJr.Reproducibility of electromyographic measures:a statistical analysis. J Oral Rehabil.1991 Nov;18(6):513-521.

[11] Helkimo E.,Carlsson GE.,Helkimo M.Bite force and state of dentition.Acta Odontol Scand. 1977;35(6):297-303.

[12] Jimenez ID.Electromyography of masticatory muscles in three jaw registration positions.Am J Orthod Dentofacial Orthop.1989 Apr;95(4):282-288.

[13] Manns A.,Miralles R.,Palazzi C.EMG, bite force, and elongation of the masseter muscle under isometric voluntary contractions and variations of vertical dimension.J Prosthet Dent.1979;42(6):674-682.

[14] Boyd CH.,Slagle WF.,Boyd CM.,Bryant RW., Wiygul JP.The effect of head position on electromyographic evaluations of representative mandibular positioning muscle groups.Cranio.1987;5(1):50-54.

[15] Abbink JH., Van der Bilt A., Van der Glas HW. Detection of onset and termination of muscle activity in surface electromyograms.J Oral Rehabil.1998;25(5):365-369.

[16] Takada K.,Yashiro K.,Morimoto T.Application of polynomial regression modeling to automatic measurement of periods of EMG activity.J Neurosci Methods.1995;56(1):43-47.

[17] Peláez A.,Gallego GJ.,Villegas LF.Confiabilidad de dos criterios de medición de la actividad electromiográfica del músculo orbicular superior de los labios durante la deglución y la fonación. Rev.Fac.Odont.UdeA.2003;15(1):67-73.

[18] Carvajal R.,Miralles R.,Cauvi D.,Berger B.,Carvajal A.,Bull R.Superior orbicularis oris muscle activity in children with and without cleft lip and palate.Cleft Palate Craniofac J.1992;29(1):32-36.

[19] Carvajal R.,Miralles MR.,Ravera MJ.,Cauvi D.,Manns A.,Carvajal A.Electromyographic and cephalometric findings in patients with unilateral cleft lip and palate after the use of a special removable appliance.Cleft Palate Craniofac J.1994 May;31(3):173-178.

[20] Carvajal R.,Miralles R.,Ravera MJ.,Carvajal A.,Cauvi D.,Manns A.Follow-up of electromyographic and cephalometric findings in patients with unilateral cleft lip and palate after fifteen months of continuous wearing of a special removable appliance. Cleft Palate Craniofac J.1995;32(4):323-327.

[21] Ravera MJ.,Miralles R.,Santander H., Valenzuela S., Villaneuva P.,Zuniga C. Comparative study between children with and without cleft lip and cleft palate,part 2: electromyographic analysis.Cleft Palate Craniofac J.2000;37(3):286-291.

[22] Susami T.,Kamiyama H.,Uji M.,Motohashi N., Kuroda T.Quantitative evaluation of the shape and the elasticity of repaired cleft lip.Cleft Palate Craniofac J.1993;30(3):309-312.

[23] Stohr M, Petruch F. Somatosensory evoked potentials following stimulation of the trigeminal nerve in man. J Neurol. 1979;220:95-98.

[24] Latman NS. Evaluation of finger blood pressure monitoring instruments. Biomed Instrum Technol. 1992; 26(1): 52-7

[25] Genaro K, F. Trindade A, S. Kiemley I, E. Electromiographic Analysis of Lip Muscle Function in Operated Cleft Subjects. Cleft Plalate Craneofac J. 1994; 31: 56-60.

[26] Kernahan DA, Bauer BS. Functional cleft lip repair: a sequential, layered closure with orbicularis muscle realignment. Plast Reconstr surg 1983; 72: 459-466.

[27] Joos U. The importance of muscular reconstruction in the treatment of cleft lip and palate. Scand J Plast Reconstr Surg 1987; 21: 109-113.

[28] Bardach J. The influence of cleft lip repair on facial growth. Cleft Palate Craniofac J. 1990; 27:76-78.

[29] Penfield W, Boldrey E. Somatic motor and sensory representation in the cerebral cortex as studied by electrical stimulation. Brain. 1937; 60:389-443. 
[30] Folkins JW, Kuehn DP. Speech production. In: Lass NJ, McReynolds LV, Northen JL, Yoder DE, eds. Speech, Language and Hearing. Vol. 1. Normal processes. Philadelphia: WB Saunders, 1982:246-285.

[31] Nicolau PJ. The orbicularis oris muscle: a functional approach to its repair in the cleft lip. Br J Plast Surg. 1983; 36:141-153.

[32] Dousset E, Jammes Y. Reliability of burst superimposed technique to assess central activation failure during fatiguing contraction. $\mathbf{J}$ Electromyogr Kinesiol. 2003; 13(2): 103-11.

[33] Buxbaum J, Mylinski N, Parento FR. Surface EMG reliability using spectral analysis. J Oral Rehabil. 1996; 23(11) 771-5.

[34] Ingervall B, Eliasson GB. Effect of hip training in children with short upper lip. Angle Orthod. 1982; 52 (3): 222-33.

Citation: Carrillo Rivera Jorge et al. Comparative Study of the Electromyographic Activity of the Lips Orbicular Muscle in Patients with and without Cleft Palate. ARC Journal of Surgery.2017; 3(4):20-27. doi: dx.doi.org/ 10.20431/2455-572X. 0304004.

Copyright: (C) 2017 Authors. This is an open-access article distributed under the terms of the Creative Commons Attribution License, which permits unrestricted use, distribution, and reproduction in any medium, provided the original author and source are credited. 